\title{
浮流物による漁船海難の現状について
}

\author{
下川 伸也** $・$ 川崎 潤二*・酒井 健一*・松本 浩文*

\section{An Investigation of the Floating Object on the Sea to Prevent the Maritime Disaster for the Fishing Boats}

\author{
Shinya SHIMOKAWA, Jyunji KAWASAKI, \\ Kenichi SAKAI and Hirofumi MATSUMOTO
}

\begin{abstract}
This study examined the actual maritime disasters of fishing boats by floating objects based on the fishing boat statistical tables and the accident data. The results are as follows: (1) The maritime disasters by floating objects occurred 15,000 a year for the entire country. (2) The maritime disasters by floating objects for less than 5GT rank fishing boats accounts for $75 \%$ of the total. (3) The difference in the maritime disaster incidences in every sea area was clarified. (4) The fishing types involved in the maritime disasters are pole and line, small bottom trawl, gill net and long line. (5) As for the floating objects producing the maritime disasters, driftwood, rope and fishing nets are often found. The injury point is concentrated in the propeller and stern part. (6) The number of accidents depends on the month. It is suggested that the disasters by increase or decrease based on the precipitation or presence of typhoons.

In the future, we must think about the connection with other factors about drift occurrence, the process when driftwood, rope and fishing nets flows out and examine the preventive measures effective against maritime disasters.
\end{abstract}

Keywords : Fishing boats, Maritime disaster, Floating object, Fishery キーワード: 漁船, 海難, 浮流物, 漁業

\section{1. はじめに}

近年、海上の浮流物や海岸漂着ゴミなどの海洋ゴミ への関心が高まり、現状調查や対策 ${ }^{(1)}$ が実施されるよう になりつつある。また、海上における浮流物は、海岸に 打ち上げられるのはほんの一部であり、相当量が海上・ 海中に存在しているとの指摘もなされている。

これらの問題としては、「景観・清潔の保持」や「観光 への悪影響」といった事ばかりではなく、「海岸保全施 設機能や漁港運営への支障といった沿岸漁業への悪 影響(2)」なども䀣念される。漁船においても操業するに あたり、これらの浮流物による衝突、接触は安全な運
航・操業に大きな障害となり、浮流物による船体や漁網 への損傷は、漁業者にとって業務を継続するにあたり 致命的ともいえる損害になりかねないことも懸念 ${ }^{(3)}$ され る。そこで、漁業者がより安全な漁業活動を継続して行 うために、浮流物による漁船海難の現状を明らかにし、 その防止策について検討することを目的とした。

\section{2. 調査資料及び方法}

一般に海難実態の分析には、海上保安庁や運輸安 全委員会、海難審判庁などによる種々の統計や原因 究明の資料を基に検討がなされることになる。しか

* 正会員 独立行政法人水産大学校 （㣙9-6595 山口県下関市永田本町 2-7-1） simokawa@fish-u. ac. jp 
しながら、同資料等には浮流物による海上事故につ いて、事故の直接的原因としては挙げられておらず、 要救助海難においても浮流物海難に特化した統計は 集計されていない。このため、本研究では要救助海 難及び海難審判庁裁決録、船舶事故調查報告書等の 資料を分析に用いることはできなかった。

\section{1 漁船保険統計表による調査}

漁船海難については、水産庁に上る漁船保険統計 表 ${ }^{(4)}$ 基に推察することが出来る。同表中の浮流物 海難は、不可抗力によるものや自然発生的に起きる などのことから、船舶間の衝突や乗揚げ、機関故障 などに関する海難事故と比心゙、海難の定義に差異が 亦ると推察されるものの、浮流物による漁船海難を 示寸有効なデータであると考えられる(5)

そこで今回、1989 年から 2008 年までの 20 年間に ついて、漁船保険統計表により浮流物海難のデータ を抽出し分析を行った。抽出デー夕は、保険申請海 難 ${ }^{(6)}$ の総数に対する浮流物海難の抽出であり、漁船 保険の適用原因に占为浮流物海難に関して、海難 の内容、船体要目、発生海域等について調査した。

\section{2 漁船保険組合別の事例調査}

浮流物海難の現状をより精査するためには、漁船 保険統計表のみでは概括的であり、さらに詳細な事 例デー夕を必要とするものと考えられる。そこで、 浮流物海難の発生件数が多く、外海・内湾・離島な ど地理的多様性があり、多岐にわたる漁業種類が行 われているなどから、長崎県及び鹿児島県における 漁船保険組合の保険請求デー夕を調査し、発生日時、 海難発生海域、漁業種類、船体要目、主機関、機関 出力などの海難発生状況、原因となった浮流物、損 傷箇所及び損害額などのデータを収集した。

長崎県においては、2007 年度に年間 1,219 件の浮 流物海難が発生しており、これらのデータを用いた。 また、鹿児島県においては、年間 420 件であり、2009 年度のデータを用いている。

\section{3. 結果及び考察}

\section{1 漁船保険による海難実態}

2008 年度におけるトン数階層別の漁船在籍隻数 と漁船保険の加入率 Fig. 1 に示す。漁船の在籍隻 数は約 30 万隻であり、そのほとんどが 5 トン未満の 漁船であることがわかる。漁船保険への加入隻数は、 195,201 隻であり国内における全漁船隻数の 64\%で ある。また、保険未加入漁船は全体の $36 \%$ を占める が、これらの漁船は 1 トン未満・年間 60 日未満の操 業日数となる漁船がほとんどであり、漁船保険への
加入義務から外れているためと考えられる。保険加 入率をトン数階層別に見ると、5 トン未満では $63 \%$ となっているが、5 トン以上の階層の漁船は 85〜 90\%の高い加入率となっている。

次に、漁船保険の適用を受けた海難の件数及び事 故率を 1989 年から 2008 年までの 20 年間の年次動向 としてFig. 2 に示す。但し、事故率は、事故発生率 として、当該年度の事故比率を表し、次式で表せる。

$$
A R=\frac{A}{\frac{1}{2} \cdot\left(N_{n-1}+N_{n}\right)} \times 100
$$

ここで、ARは事故率、 $A$ は当該年度事故件数、 $N_{\mathrm{n}-1}$ は前年度引受隻数、 $N_{n}$ は当該年度引受隻数を示す。

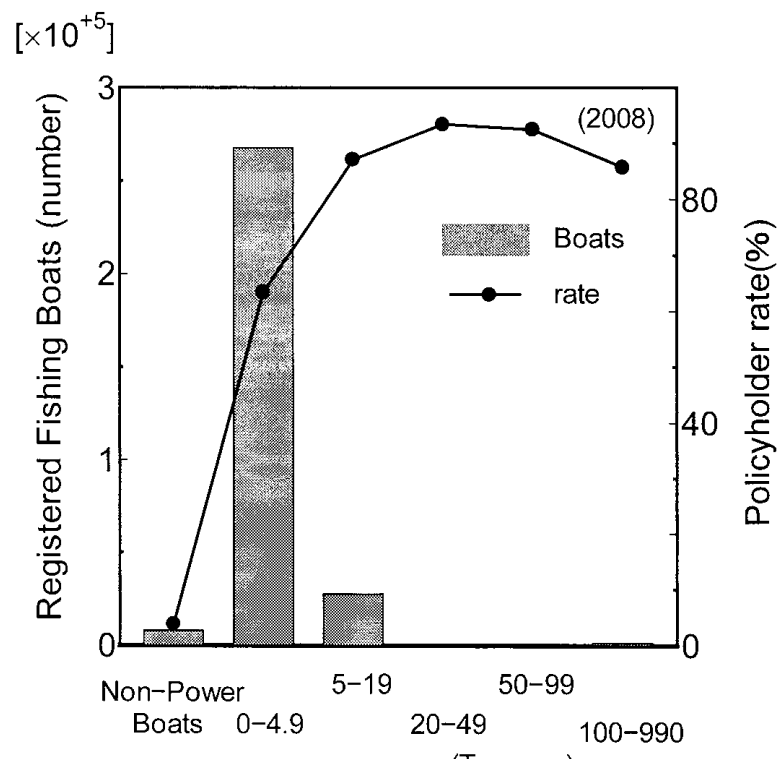

(Tonnage)

Fig. 1 The number of enrollment and insurance subscription rate of fishing boats

$\left[2 \times 10^{+4}\right]$

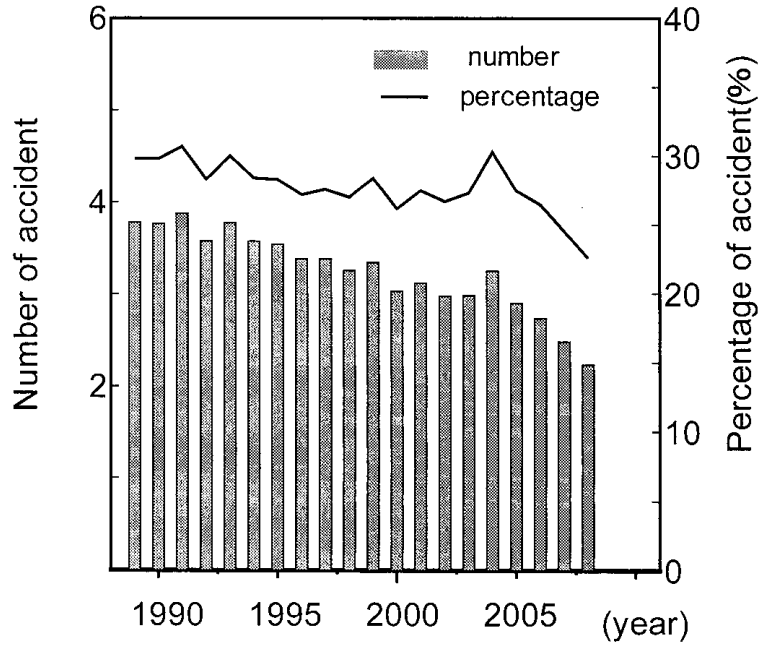

Fig. 2 The accident number and rate of accident by fishing boats insurance 
海難件数は、1991 年の 77,532 件をピークに減少 傾向が見られ、2008年では44,547 件となっている。 また、事故率は 25 30\%で推移し、2005 年以降には 減少傾向が顕著となっている。漁船保険の適用を受 けた海難の原因別事故件数を Fig.3に示す。2008 年度 に 44,547 件発生した海難のうち“浮流物(浮流物との衝 突、接触)”によるものは、約 30\%の 13,448 件となり、次 いで、“操船上 (操舵の溃り等)”、“てん絡(漁具等が推 $\left[\times 10^{+4}\right]$

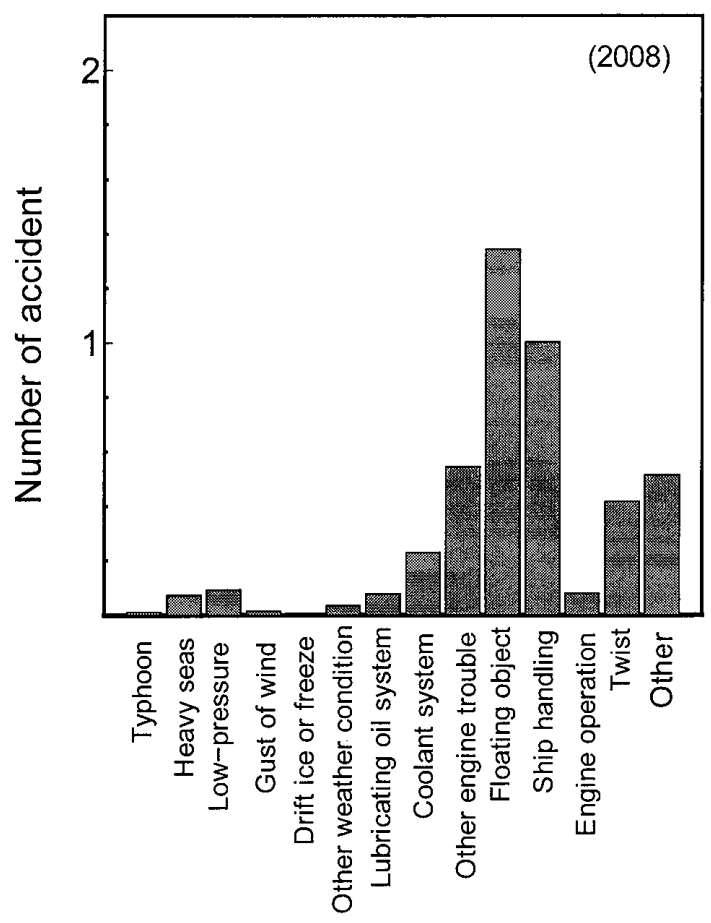

Fig. 3 The accident number according to cause $\left[\times 10^{+4}\right]$

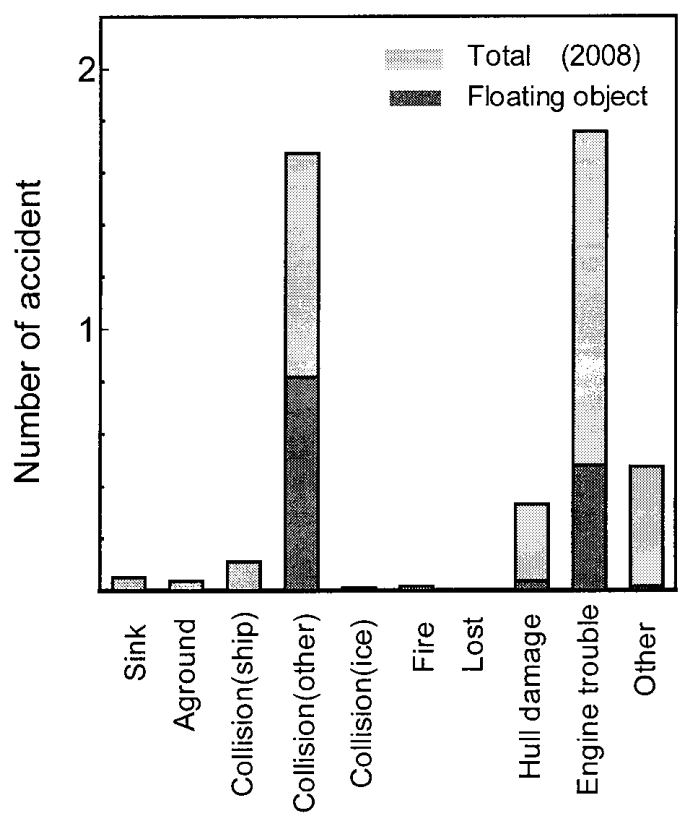

Fig. 4 The accident number according to accident type
進器または推進軸にまきつくこと)”などが原因となって いる。他に挙げられる海難原因としては、“台風”、“風 浪”などの気象要因、“潤滑油系統”や“冷却水系統”を 含む機関故障の要因と共に、“浮流物”、“操船上”、 “操機上”などの漁船の運用に関する要因が原因とな ることが伺えた。

Fig.4 に事故種類別の事故件数を示す。図中、浮流 物によるものを、それ以外の事故種類と区別して表示し ている。「衝突」の項目は、“船舶間の衝突”、“水との衝 突”及び“それ以外の衝突”と 3 段階に分類されており、 保険海難では、“船舶以外との衝突”と“機関故障”にお いて、それぞれ 38\%、40\%と突出して多く事故が発生し ていることが伺える。また、浮流物による海難に限定す ると 13,448 件中で、“船舶以外との衝突” 8,154 件

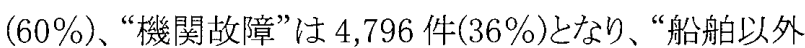
との衝突”による事故が、より多く見られる結果となって いた。これは、一般的に多いとされる海難種類である船 舶との衝突、乗揚げ、機関故障等とは異なる傾向であ 万。

\section{2 浮流物海難の発生状況}

浮流物による海難の発生状況として、トン数階層 別の事故件数と事故発生率 Fig. 5 に示す。事故件数 は、Fig.1 に示したトン数別の在籍隻数を反映し、 5 トン 未満の階層において、最も発生件数が多く $75 \%$ を占 め、次いで、5-19 トンの階層での事故が発生する傾 向が見られる。事故発生率においては、5-19トンの 階層で約 16\%と高く、次いで、20-49トンの階層、5 トン未満の階層において $7 \%$ 程度となっていた。こ のように、浮流物海難の発生において 5-19 トンの階

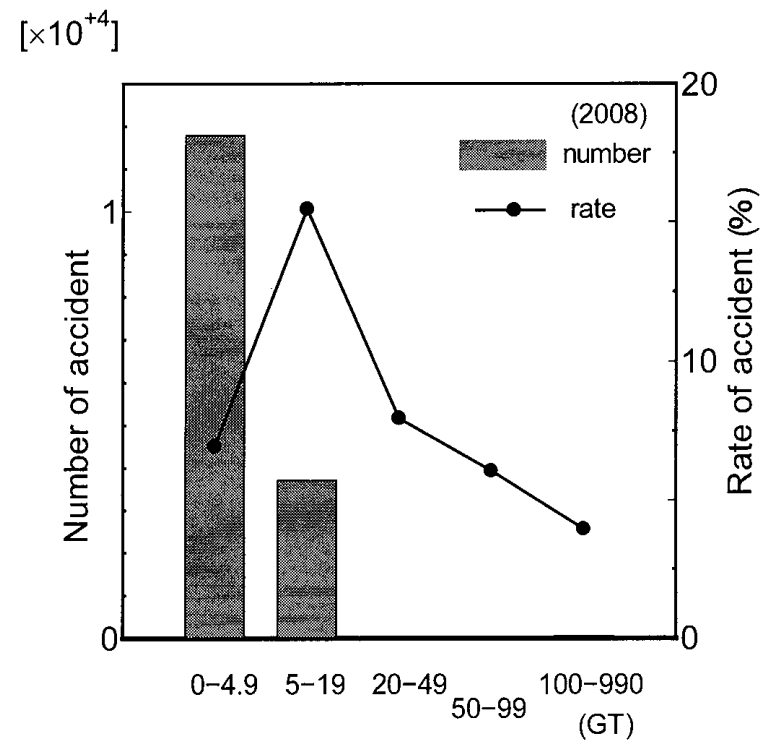

Fig. 5 The accident number and rate of accident by floating object according to tonnage rank 


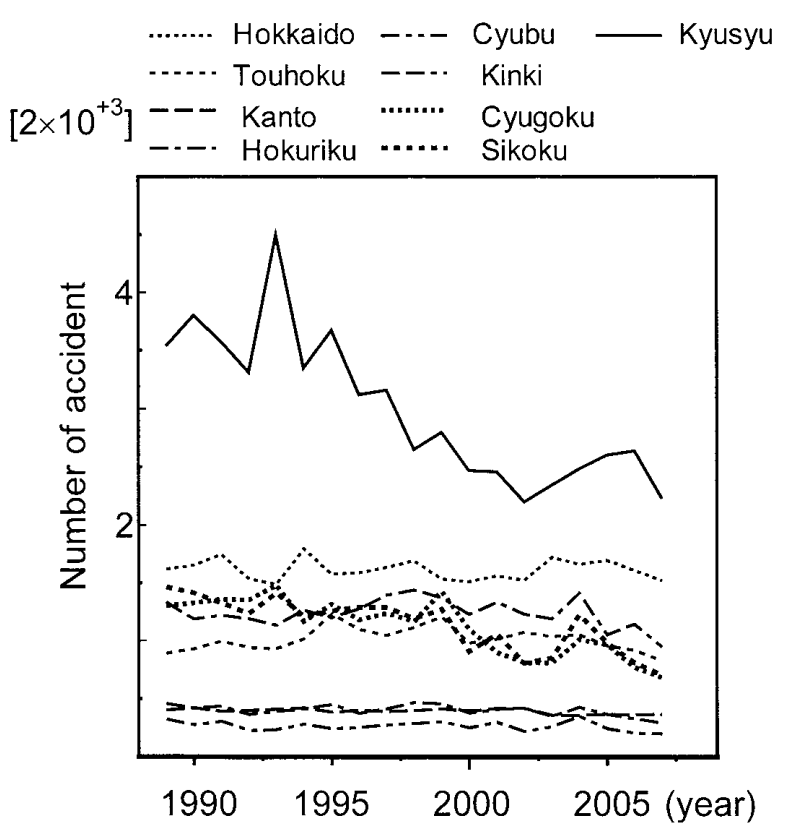

Fig.6(a) The accident number of accident by floating object according to rural areas

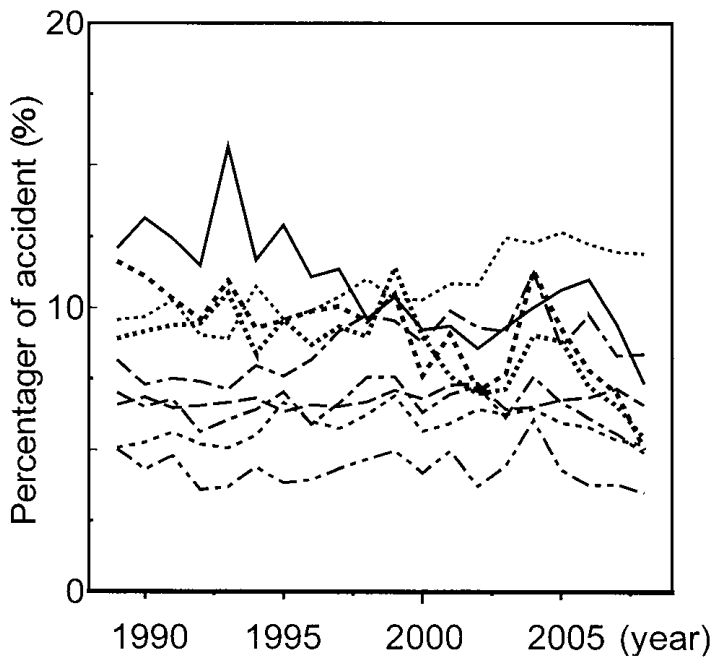

Fig. 6(b) The accident rate of accident by floating object according to rural areas

層で事故発生率が高くなるのは、小型漁船ではある ものの、船規模に余裕があり、航続距離、航海時間、 通常船速などの増大が、浮流物との遭遇機会を増加 させ、結果として事故発生率の高さに表れたものと 推察された。

次に、浮流物による海難の発生海域を地方別に分 類し、事故件数の推移を Fig.6(a)に、事故率を Fig.6(b) にそれぞれ示す。地方別の事故件数では、九州地方で 他の地方と比べ突出して多く発生し、減少傾向は見ら れるものの継続していることがわかる。次いで、北海道 地方が多く、20 年間ほぼ同数の事故件数で推移してい る。事故率では、九州地方は 10 年程前加減少傾向を
示して他地方と同程度の事故率となっているが、北海 道地方では増加する傾向が伺え、他地方よりも高い事 故率となっていることがわかる。

\section{3 浮流物海難の事例調查結果}

浮流物海難の詳細を調査するため、事故漁船が個 別に保険を請求する手続きとして提出された漁船再 保険金支出請求書から、事故分析に必要なデ一タを 抽出した。データの範囲は、九州地方において浮流 物海難の発生件数が多いことを考慮し、長崎県及び 鹿児島県としている。調查したデータ項目は、海難 発生状況、原因物、破損箇所、発生年月日、発生時 間、漁業種類などで、各県ともに 1 年間分の全デー タとして、長崎県における 2007 年度分の 1,219件、 鹿児島県における 2009 年度分の 420 件を対象とし た。

事例調查による海難発生状況を整理した結果を Fig. 7 に示す。図中、上段を鹿児島県、下段を長崎 県として示し、上から漁業種類、運航状況、事故発 生時間帯、主機出力及び船齢を示している。漁業種 類別では、一本釣り、小型底曳き、刺網及び延縄で 多く発生し、全体の7割を占めていた。運航状況で は、往航、帰航、操業の 3 種類に分類し、鹿児島県 では往航時、長崎県では帰航時に多く事故が発生し ていた。事故発生時間帯では、4 時から8 時までの 時間帯で多く、次いで、8 時から 12 時までとなり、 午前中の時間帯で多く発生する傾向が伺えた。この ことは、操業に向けて漁場へ向から移動航行中に、 午前中の太陽高度が低い時間帯で海面が見づらい状 況や操業準備などにより海面監視が十分でないなど

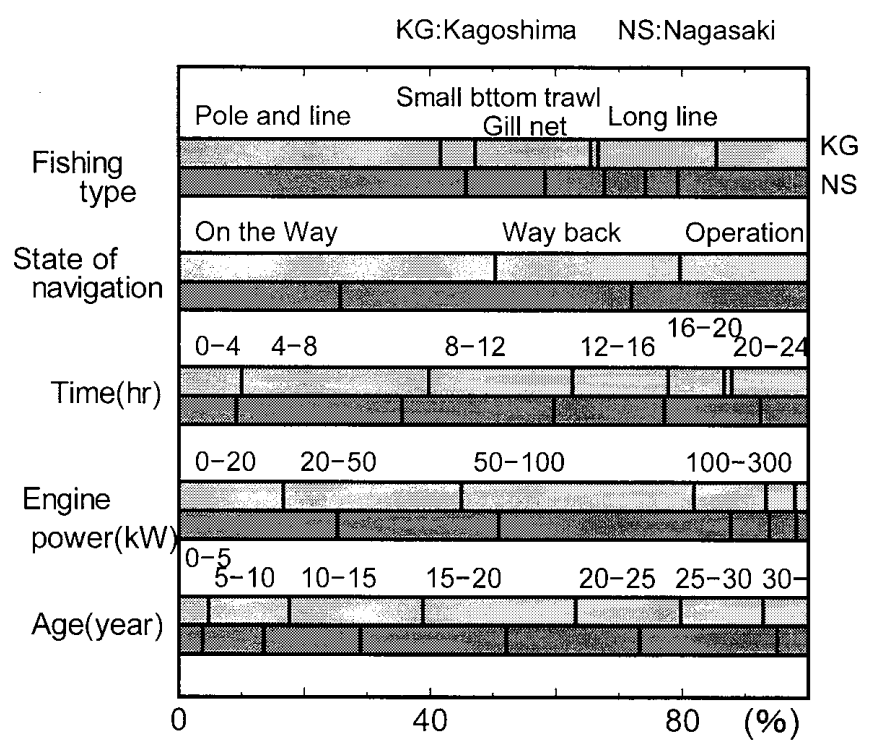

Fig. 7 The generating situation of the accident by floating object 
により、浮流物に気づかなかったことが推察される。 主機出力別では、50-100kW の出力範囲で多く発生し、 それ以外は小出力の漁船で多く発生する傾向を示し ていた。船齢別では、船齢 10 年から 30 年までの範 囲で広く分散し、新旧の違いによる特徵は見出せな かった。

さらに、原因となった浮流物の種類としては、流 木によるものが $27 \%$ 、ロープ・漁網類が $19 \%$ となっ ており、全体の 54\%は未確定として種類を特定でき ない結果となった。この原因としては、浮流物が船 底に潜り込み視認が不可能であったことなどが考え られ、未確定ではあるものの、そのほとんどは、他 の種類の浮流物であることは考えにくく、大半は流 木、ロープ・漁網等に分類されるものと推察された。

次に、事故損傷箇所別の事故発生率を Fig. 8 に示 す。発生率の值は、事故により複数箇所の損傷が多 く見られ、1 件の海難でも複数の箇所で集計した結 果である。損傷箇所として、両県ともにプロペラ部 の損傷が $75 \%$ 程度と圧倒的に多い結果となってい た。また、プロペラ軸の損傷は、長崎県において $35 \%$ 程度、鹿児島県においても16\%程度とそれぞれ多い 割合を占めていた。その他の損傷筒所としては、船 体、舵関係、ドライブ、ソナー関連なよ゙で損傷が見 られた。損傷を受ける場合、プロペラが損傷を受け ると同時にプロペラ軸も損傷するなど、装備上で連 動している箇所が同時に損傷を受ける例が多く見受 けられた。また、ソナー関連の損傷では、事故件数 は少ないものの、損傷による損害額が高額となる傾

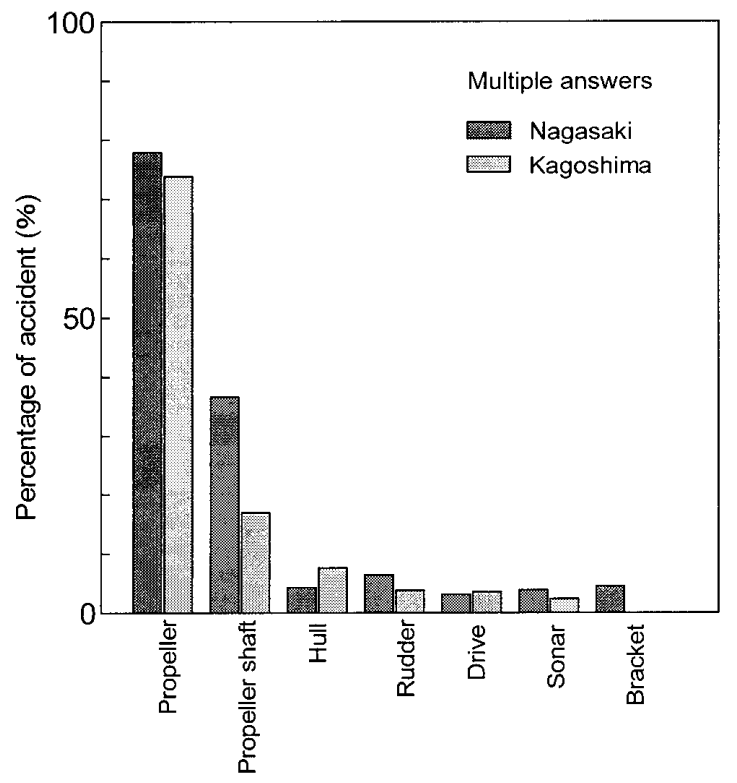

Fig. 8 The damage part of the accident by floating object
向が見られた。

損傷箇所の特徴により、損傷が船尾部に集中する ことを考慮すれば、推進力の低下に懸念はあるもの の、プロペラガードなどを用いて、船尾部や特にプ ロペラ周辺への保護対策を考慮する必要があるもの と考えられた。

\section{4 海難発生要因の検討}

浮流物海難の発生に影響する要因について検討す るため、長崎県における 2007 年度の月別の浮流物海 難発生件数と長崎市に掠ける月間降水量との関係を Fig. 9 に示す。月別の変動について、事故件数と降

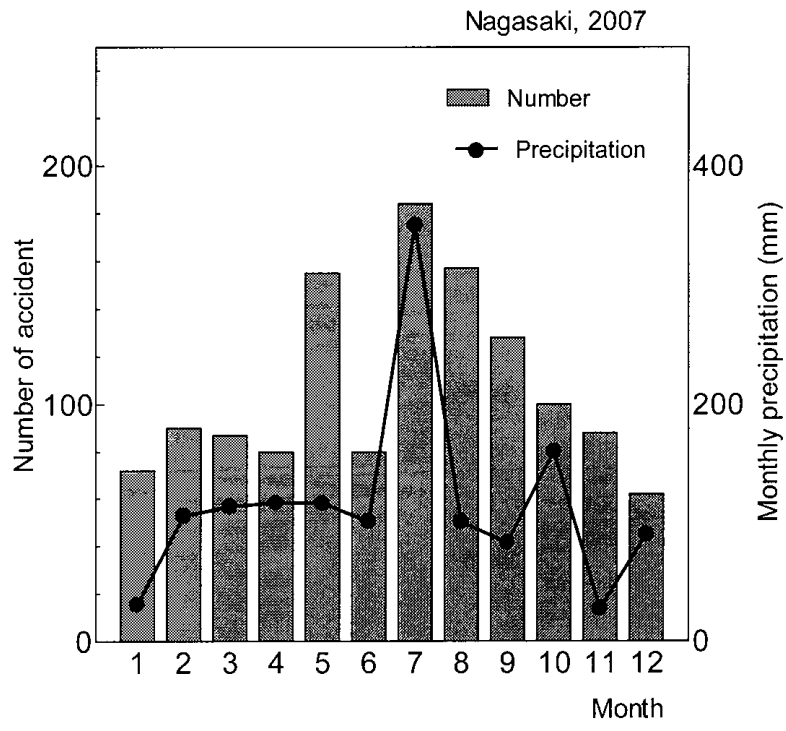

Fig. 9 Relation between the accident number and precipitation

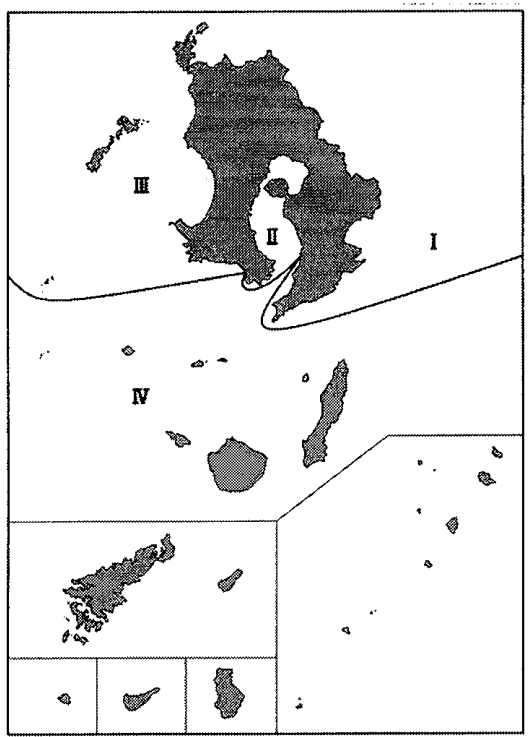

Fig.10 Division of sea area 


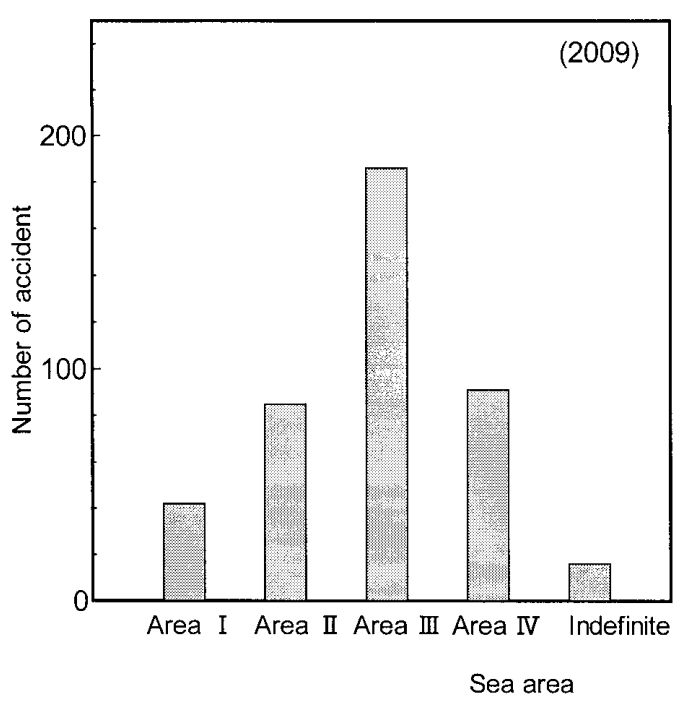

Fig.11 The accident number according to sea area

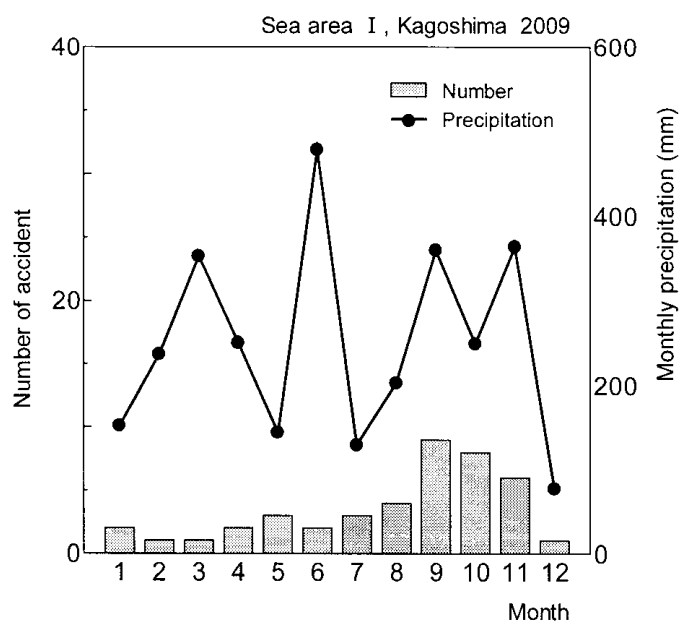

Fig.12(a) Relation between the accident number and precipitation (sea area I )

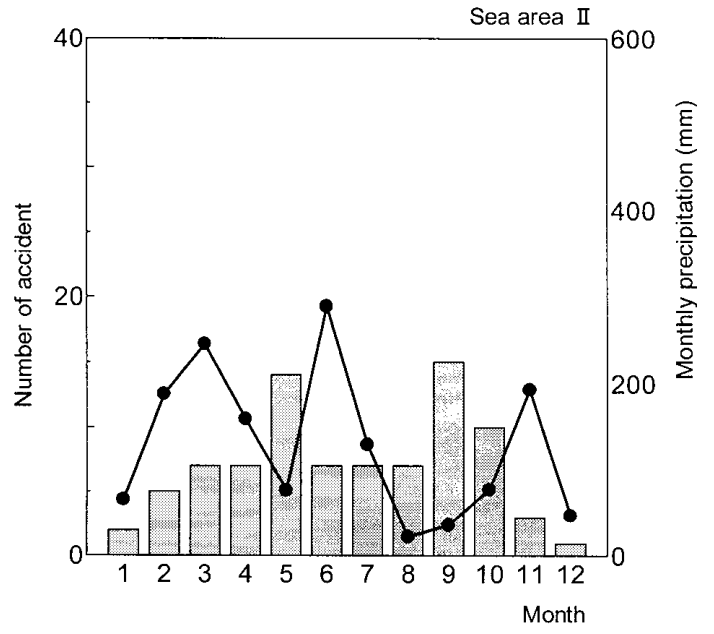

Fig. 12(b) Relation between the accident number and precipitation (sea area II )
水量の傾向が類似していることがわかる。特に、7 月の梅雨期に降水量と共に事故件数も増加し、翌月 以降に降水量は少なくなるものの、事故件数は増加 したまま 2 ケ程度継続しながら減少している。こ れは、流木などが海上に浮流物として流出する影響 要素として、降雨により陸上から河川に流れ出し、 その後、沿岸域に達して海上を浮流することとなり、 結果として小型漁船の浮流物事故へと影響を及ぼす ことになったものと推察される。

さらに、浮流物への影響要因について検討するた め、鹿児島県の事例を基に、同県の海域を 4 分割し 海域別の事故発生の特徵について検討した。分割例 をFig. 10 に示す。大隅半島東岸海域を海域 I 、鹿児 島湾内を海域 II 、薩摩半島西岸海域を海域 II 、南方 諸島海域を海域IVとして分割している。海域の特徴 として、海域 I では、付近沿岸の東方を黒潮流が北

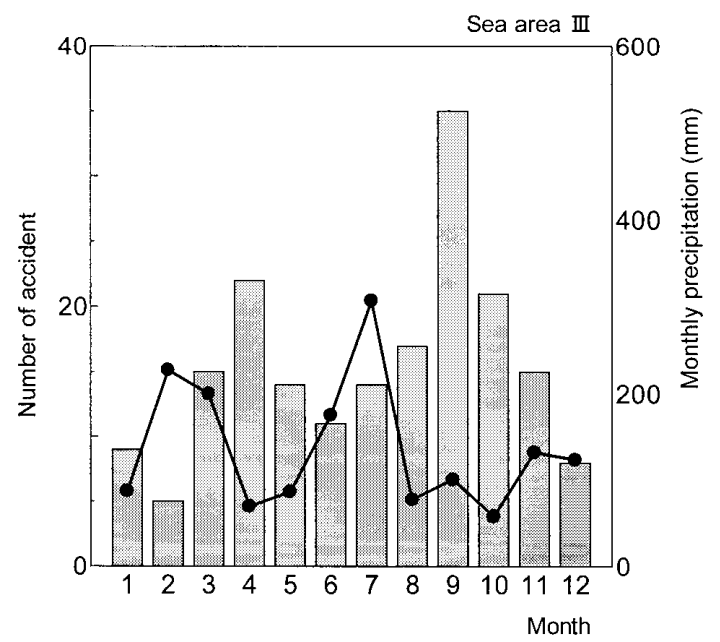

Fig. 12(c) Relation between the accident number and precipitation (sea area III)

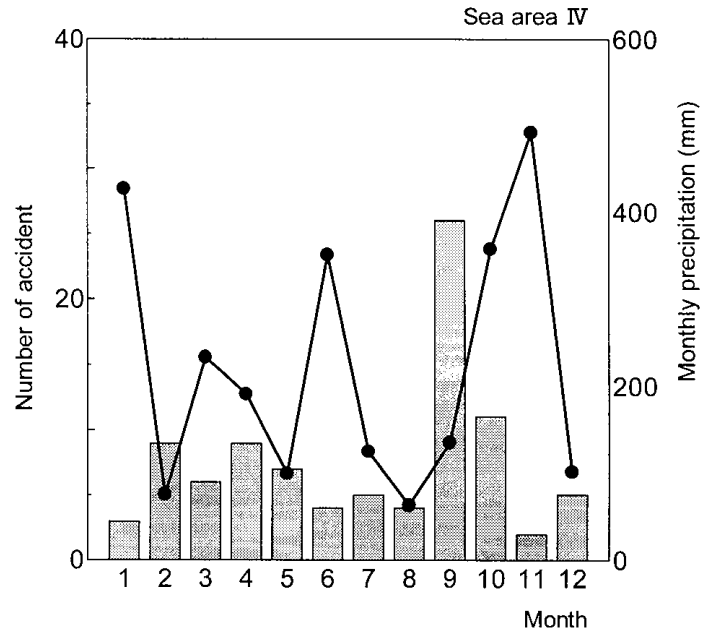

Fig. 12(d) Relation between the accident number and precipitation (sea area IV) 
流として流れている。海域 I は内湾であり、海域 III は黒潮の支流と薩摩半島からの河川が多く存在して いる海域となっている。さらに、それら以外の海域 IVでは、鹿児島県南方の島嶼部となっている。海域 別の事故発生件数を Fig.11に示す。海域IIIにおいて 事故件数が最も多く、年間 186 件発生していること がわかる。このことは、地理的に河川が多く存在し ており、河川と浮流物との関連があるものと考えら れる。

さらに、浮流物海難との関連について、災害の発 生状況と海難発生との関連について検討した。鹿児 島県において 2009 年度中に浮流物に影響があった と思われる災害は、以下の 3 件が挙げられる。1 件 目は2009年 2 月 24〜25 日の間に鹿児島県全域にお いて、副振動によるとされる海面上昇が発生してい る。これにより、陸上の流木等が沿岸海域に流出し たと考えられる。この災害による被害は、海域而に おいて漁船約 30 隻が、転覆、沈没したとの報告もな されている。2 件目は、9月上旬に発生した、鹿児島 沿岸海域への大量の流木漂着が挙げられる。同年 8 月に発生した台風 8 号が台湾本島を直撃し、そこか ら大量の流木が流出したとされ、流出後の流木が 9 月上旬に鹿児島県全域の海域に漂着したとされてい る。その後の流木回収作業で、鹿児島周辺海域にお いて 10,000 本以上の流木が回収された災害である。 3 件目は、鹿児息県への影響台風として、台風 18 号 が強い勢力のまま鹿児島県東方海域を通過したこと が挙げられる。最接近したのは10月 7 日であり、家 屋や漁船に被害が出たとされている。これらの災害 により、浮流物が海上に流出したものと考えられる。 これら鹿児島県における災害状況と合わせて考察 するため、海域別の事故件数と降水量の関連を Fig. 12(a)から Fig. 12(d)までに示している。河川の 少ない海域IVを除き、降水量のピーク值を示した月 から約 2〜3 ケ月後に事故件数が増学る傾向が伺え る。このことから、降水量が増えると河川を通して、 漁船の浮流物海難に影響のある浮流物の流出量が増 え、結果として事故が多くなるものと考えられた。 また、海域 I では降水量は多い数值が示されている ものの、河川が少なかったり、付近海域に潮流影響 を受け、浮流物が流され付近海域に滞留せずに流さ れたりしたことが影響したものとも考えられる。島 嶼部である海域IVでは、海域が広範囲であり、ここ では名瀬市の降水量を示しているが、1月と 11 月の 降水量が多いものの全般的に降水量が多く、事故件 数との関連は見られない結果となっていた。さらに、 災害発生との関連では、各海域ともに災害が発生し
た後の 9 月、10月に多くの事故が発生し、4 月、5 月にも事故が増える傾问が伺える。このことから、 災害発生後や梅雨期以降に洋上の浮流物回収を行う と効果が高いと考えられた。

\section{5 浮流物海難の予防対策}

本研究において明らかとなった浮流物海難の発生 状況や事故発生の要因をまとめ、予防対策について 考察を行った。浮流物による海難を防止し、安全を 確保するためには、漁船運航上の対策と予防するた めの措置について考慮する必要があるものと考えら れた。すなわち、運航上の対策としては、浮流物の 発見のための見張りの強化、プロペラ損傷による運 航阻害を解消するための連絡手段の確保、さらに、 事故発生時の安全性を高めるために 2 隻以上での操 業や航行を行うなどが考えられる。また、予防措置 としては、浮流物の流出が想定される時期を考慮し て、河川からの流出防止対策を実施したり、海上に おいて浮流物の回収体制を構築または強化したりす る必要が女る。また、船体への予防措置としては、 推進力の低下を配慮しつつも安全確保の観点から、 プロペラガードなどの保護装置を装着するなどの対 策が考えられた。

\section{4. まとめ}

今回、漁船保険統計表等の資料及び長崎県及び鹿 児島県漁船保険組合の保険請求データを基に、浮流 物による漁船海難の現状について検討を行った。そ の結果、（1）全国で 1 年間に発生する浮流物を起因 とする海難は、1 万 5 千件程度発生している。（2）浮 流物海難は、総トン数 $5 \mathrm{t}$ 未満の階層で全件数の $75 \%$ を占める。（3）海域別海難発生率の違いを明ら かにした。(4) 浮流物海難の発生が多い漁業種類は、 一本釣り、小型底曳き、刺網及び延縄である。（5）海 難を発生させている浮流物は、流木、ロープ・漁網 等がほとんじであり、損傷箇所は、プロペラ等船尾 部に集中する。（6）発生件数は、月毎に異なり、原 因として降水量の増減や台風などの災害影響が考え られる。また、予防対策について考察を行った。そ の結果、運航上の対策として、浮流物発見のための 見張り強化、連絡手段の確保、2 隻以上での運航体 制などが挙げられるとともに、予防措置として、浮 流物の流出防止策、回収体制の構築または強化、さ らに、船体損傷を予防する保護装置の装着などが考 えられた。

今後は、浮流物の発生について、さらに他の要 因との関連や海洋への流木・ロープ・漁網等の流出 
するプロセス、有効な海難防止策等を検討する必要 がある。

\section{謝辞}

本研究を進めるにあたり、調査に対し全面的にご 協力いただいた、長崎県漁船保険組合、鹿児島県漁 船保険組合及び沖縄県漁船保険組合の皆様に感謝の 意を表します。

\section{参考文献}

（1）富永雄一: 船舶の航行安全対策と海洋ゴミ問題, 海と安全, No. 549，pp. 31-34，2011.

（2）(社)日本海難防止協会編：海のゴミ，海と安全， No.514，pp.1-39， 2002.

（3）吹上圭一：海洋ゴミによる漁船の被害状況につ いて，海と安全，No. 549，pp. 51-52， 2011.

（4）漁船保険統計表：水産庁漁政部漁業保険課，水 産庁発行, 1989 年度版-2008 年度版.（20 年分）

（5）下川伸也・川崎潤二・酒井健一：漂流物による 漁船の海難実態, 平成 22 年度水産工学会学術講 演会論文集，pp. 165-168，2010.

（6）三宅哲夫：漁船保険概説，成山堂書店， 1988.

\section{質疑応答}

嶋田陽一 (神豆大学) :

貴重なご講演ありがとうございました。

（1）浮流物による海難は、漁船が出発するとき に事故が多いのですか。漁船が漂流中に網がプ ロペラ付近に漂い、出発時に網がプロペラに絡 まって事故が発生するのかと思いました。

（2）流木が国内（鹿児島）だと、どこの河川か らなのか。川内川なのでしょうか。また、大陸 からの浮流物は、対馬海峡を流れるケースが多 いと思いました。

\section{下川伸也：}

（1）漁船では網や縄などの漁具を用いて操業 が行われますが、その取扱は注意深く行われて います。また、今回明らかとなった海難の発生 状況によると、漁港から漁場へ向から往復の航 海中に多くの事故が発生していることからも、 漂流中に自船の漁具をプロペラ等に絡めるこ とは少ないものと考えられます。

（2）特定の河川から流木が流出する状況につい ては調査しておりません。今回、鹿児島県の海 域を分割して事故件数を検討した結果、川内川 （一級河川）の存在する海域IIIで多く発生して おり、大きな河川ほど海洋への浮流物流出の影
響は大きいものと考えられます。また、外国由 来の浮流物は、海流の影響が大きく、ご指摘の 通りだと思います。本論文では、2009 年度にお いて台湾本島から流出した大量の流术が、鹿览 島地方へ被害をもたらした災害と併せて考察い たしました。 